\title{
SIMULÁCIA POVODNE NA ONDAVE
}

\section{FLOOD SIMULATION ON THE ONDAVA RIVER}

\author{
Jakub Mydla ${ }^{*}$, Andrej Šoltész $^{1}$, Martin Orfánus ${ }^{1}$
}

jakub.mydla@stuba.sk

${ }^{1}$ Slovenská technická univerzita v Bratislave, Stavebná fakulta, Radlinskeho 11, 81005 Bratislava

\begin{abstract}
Abstrakt
Príspevok sa zaoberá matematickou simuláciou povodne, ktorá postihla dolný tok Ondavy v roku 2010. Simulácia skúmala za pomoci 1-D modelovania hladinový režim v toku, pretečené množstvo vody cez bočný priepad a pomocou 2-D modelovania zatopenú plochu mimo hrádzového územia. Príspevok sa d’alej zaoberá alternatívnym znížením hrany priepadu a aj vybudovaním poldra, ktorého úlohou je zníženie zaplavenej plochy. Simuláciami bolo zistené, že aj napriek vplyvu bočného priepadu zabezpečia ochranné hrádze bezpečné odvedenie prietoku, len s periodicitou menšou ako 10 rokov.
\end{abstract}

\section{Kl'účové slová}

Povodeň, Matematické modelovanie, HEC-RAS, Bočný priepad

\begin{abstract}
Contributions deals with a mathematical simulation of the flood that affected the lower Ondava in 2010. The simulation examined 1-D modelling of the level regime in the stream, the amount of water flowing through the lateral spillway, and 2-D modelling the flooded area outside the dike area. Contributions also deal with the alternative reduction of the spillway edge and the construction of a polder, the task of which is to reduce the flooded area. The simulations revealed that, despite the influence of the side overflow, the protective dikes would ensure safe drainage, only with a periodicity of fewer than 10 years.
\end{abstract}

Key words

Flood, Mathematical modelling, HEC-RAS, Lateral spillway

\section{1 ÚVOD}

Ondava je významná východoslovenská rieka, ktorá je v súčasnosti výrazne ovplyvnená l’udskou činnost'ou. V strednej časti toku je od roku 1967 v prevádzke vodné dielo Vel'ká Domaša, ktoré má výrazný vplyv na prietokové pomery $\mathrm{v}$ nižších častiach toku. V dolnej časti je tok obojstranne ohradzovaný zemnými sypanými hrádzami. Slovenský vodohospodársky podnik (SVP) sa v nedávnej histórii dolnej Ondavy potykal s 2 ničivými povodňami. Povodeň v roku 2004 presiahla dovtedy známe maximá zaznamená vo vodomernej stanici Horovce a spôsobila pretrhnutie l'avej ochrannej hrádze (L’OH) zhruba $500 \mathrm{~m}$ nad čerpacou stanicou (ČS) Ladislav [1]. Obr. 1 zobrazuje záujmové územie. Druhá ešte výraznejšia povodeň nastala v roku 2010. Táto povodeň sa vyznačovala dvomi špičkami prietokov, pričom kulminácia prekonala maximum aj z 2004 roku. Počas tejto povodne došlo k pretrhnutiu pravostrannej ochrannej hrádze $(\mathrm{POH})$ a následnému prekopaniu LOH pracovníkmi SVP [2].

Spomínané povodne si našt'astie nevyžiadali obety na životoch. Zaliali, však vel'kú čast' pol'nohospodársky využívanej VSN. Bola nutná evakuácia obyvatel'stva a vznikli aj významné náklady pre SVP spojené s opravou ochranných hrádzi a odstraňovaním povodňových škôd. Všetky tieto problémy boli spojené s pretrhnutím ochranných hrádzí. Na zamedzenie pretrhnutia ochranných hrádzí bol vybudovaný v roku 2005 pevný bočný priepad na LOH v mieste pretrhnutia hrádze v 2004 roku. A práve takéto netradičné riešenie odl'ahčenia povodňových prietokov bolo hlavnou motiváciu na skúmanie odtokových pomerov na dolnej Ondave.

Príspevok sa d'alej venuje hladinovému režimu v úseku Horovce - Hraň, pri simulácii povodne z roku 2010. Na skúmanie povodne sa využil program HEC-RAS a to 1-D a 2-D matematické modelovanie, ktoré sa zaoberalo hladinovým režimom v toku, kapacitou a funkčnost’ou priepadu (1-D) a zatopenou plochou územia (2-D). Pri modelovaní sa uvažovalo s nepoškodením ochranných hrádzí a s prelievaním vody do mimo hrádzového priestoru výlučne cez bočný priepad. 


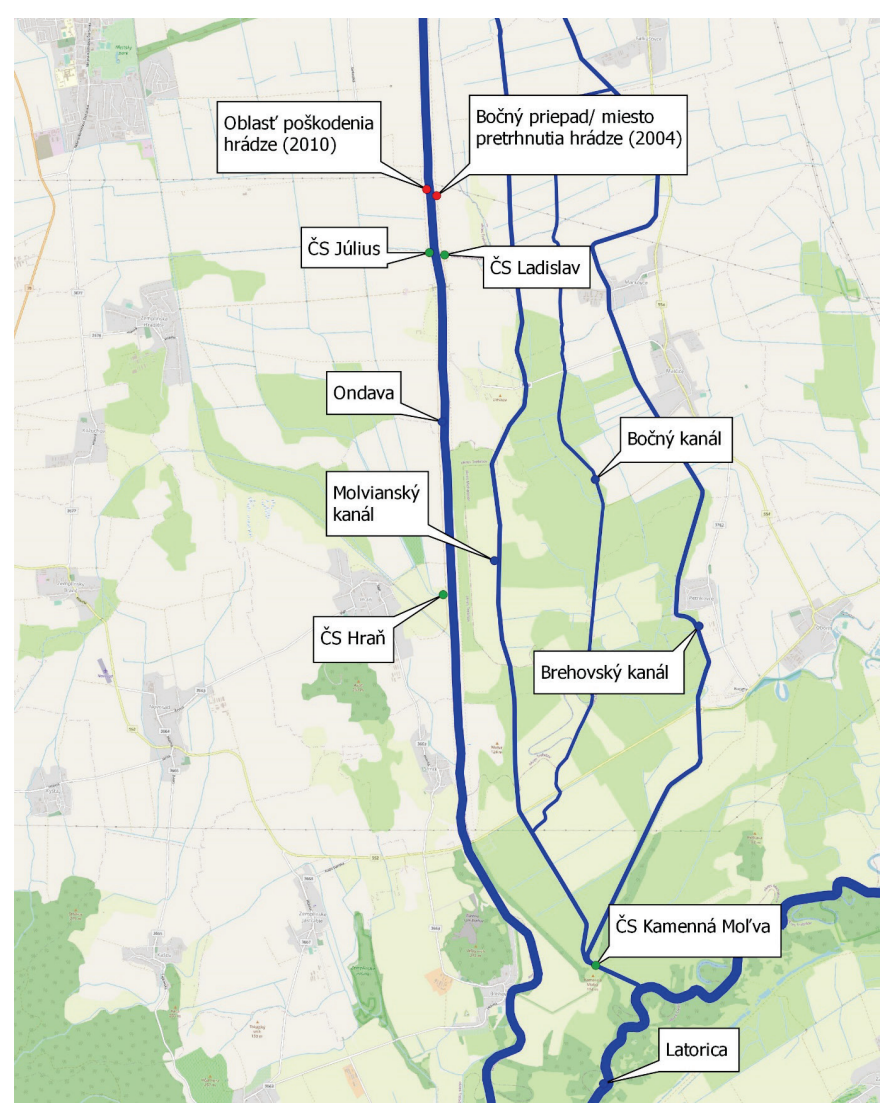

Obr. 1 Prehl'adná situácia záujmovho územia.

\section{CHARAKTERISTIKA ÚZEMIA}

\section{Geomorfológia a klimatické podmienky}

Pre VSN v okolí dolnej Ondavy je charakteristický minimálny sklon územia s množstvom depresných plôch, ktoré boli vytvorené prevažne riečnou činnost'ou. Geologická štruktúra je tvorená riečnou akumuláciou pričom ju dotvorila veterná činnost'. Územie spadá podl'a klimatickej klasifikácie do teplej a mierne suchej až suchej oblasti s kontinentálnym typom podnebia. Skúmané územie leží na rozhraní okresov Trebišov a Michalovce (Košický kraj). Na záujmovom území ležia 4 ČS. Na pravej strane sú to ČS Július a Hraň, na l'avej strane Ondavy je ČS Ladislav a v južnej časti tejto oblasti je ČS Kamenná Mol'va, ktorá odvádza vnútorné vody do toku Latorice [3].

\section{Hydrologické charakteristiky}

Z hydrologického hl'adiska je modelované územie považované za oblast' so zložitými odtokovými pomermi, kde depresné časti sa dajú považovat' za bezodtokové. Na prietoky dolnej Ondavy má výrazný vplyv jej najväčší pravostranný prítok Topl'a. V mieste sútoku majú tieto rieky podobné hydrologické charakteristiky (plocha povodia, priemerný ročný prietok). Pri odtokovom režime hovoríme o dažd'ovo-snehovom, ktorý sa vyznačuje jarnou zvýšenou vodnatost'ou a v auguste/septembri sú prietoky iba polovičné voči priemernému ročnému prietoku. Takéto rozloženie prietokov je spôsobené topením tuhých zrážok v horných častiach povodia, ktoré je často do prevádzané dažd'ami [3]. Niektoré hydrologické charakteristiky týchto riek bez účinku Vel'kej Domaše nám zobrazuje Tab. 1 . 
Tab. 1 Hydrologické charakteristiky Ondavy a Tople [4].

\begin{tabular}{|c|c|c|c|c|c|c|c|}
\hline Profil & $\begin{array}{c}\text { Plocha } \\
\text { povodia } \\
{\left[\mathrm{km}^{2}\right]}\end{array}$ & $\begin{array}{c}\text { Priem. } \\
\text { ročný } \\
\text { prietok } \\
{\left[\mathrm{m}^{3} \cdot \mathrm{s}^{-1}\right]}\end{array}$ & $\begin{array}{c}\mathbf{Q}_{1} \\
{\left[\mathbf{m}^{3} \cdot \mathbf{s}^{-1}\right]}\end{array}$ & $\begin{array}{c}\mathrm{Q}_{5} \\
{\left[\mathrm{~m}^{3} \cdot \mathbf{s}^{-1}\right]}\end{array}$ & $\begin{array}{c}\mathbf{Q}_{10} \\
{\left[\mathbf{m}^{3} \cdot \mathbf{s}^{-1}\right]}\end{array}$ & $\begin{array}{c}\mathbf{Q}_{20} \\
{\left[\mathrm{~m}^{3} \cdot \mathbf{s}^{-1}\right]}\end{array}$ & $\begin{array}{c}\mathbf{Q}_{100} \\
{\left[\mathbf{m}^{3} \cdot \mathbf{s}^{-1}\right]}\end{array}$ \\
\hline Ondava - nad Topl'ou & 1341 & 10,2 & 165 & 337 & 413 & 495 & 710 \\
\hline $\begin{array}{l}\text { Topl'a ústie do } \\
\text { Ondavy }\end{array}$ & 1552 & 10,8 & 123 & 258 & 325 & 392 & 560 \\
\hline Ondava - Horovce & 2883 & 21,3 & 240 & 440 & 530 & 620 & 830 \\
\hline
\end{tabular}

\section{PODKLADOVÉ MATERIÁLY A METÓDY RIEŠENIA}

Na výpočet hladinového režimu v toku bol použitý matematický 1-D model zostavený v programe HEC-RAS. Miera záplavy sa riešila 2-D matematickým modelom v tom istom softvérom prostredí, pričom boli vzájomne prepojené. Na zostavenie takto komplexného výpočtu sú potrebné morfologické charakteristiky (priečne profily toku a digitálny model terénu - DTM), ktoré boli poskytnuté SVP a hydrologické údaje, ktoré poskytol Slovenský hydrometeorologický ústav (SHMÚ).

\section{Morfologické podklady}

Celková morfológia územia bola určená na základe DTM, ktoré pozostáva z výškovo a priestorovo určených bodov (červené body) a z terénnych hrán, ktoré dobre vystihujú zmeny v sklonitosti terénu (zelené čiary). Príklad menšieho úseku DTM znázorňuje Obr. 2, na ktorom si môžeme všimnút' aj modré čiary, ktoré zaznamenávajú polohu hladiny v Ondave a v kanáloch počas vyhotovovania mapy. Ked’že pod hladinou vody nevieme z DTM vyčítat' tvar koryta, tak bol použitý model terénu doplnený o priečne profily od Horoviec až po ČS Hraň. Overenie presnosti poskytnutého modelu prebehlo geodetickým zameraním. Pri meraní sa zistilo, že DTM je dostatočne presný a $\mathrm{k}$ jeho úprave došlo iba v mieste vybudovaného priepadu. Z týchto podkladov už bolo možné vytvorit' za pomoci programov AutoCad a ArcGIS geometriu pre matematický model prúdenia [5].

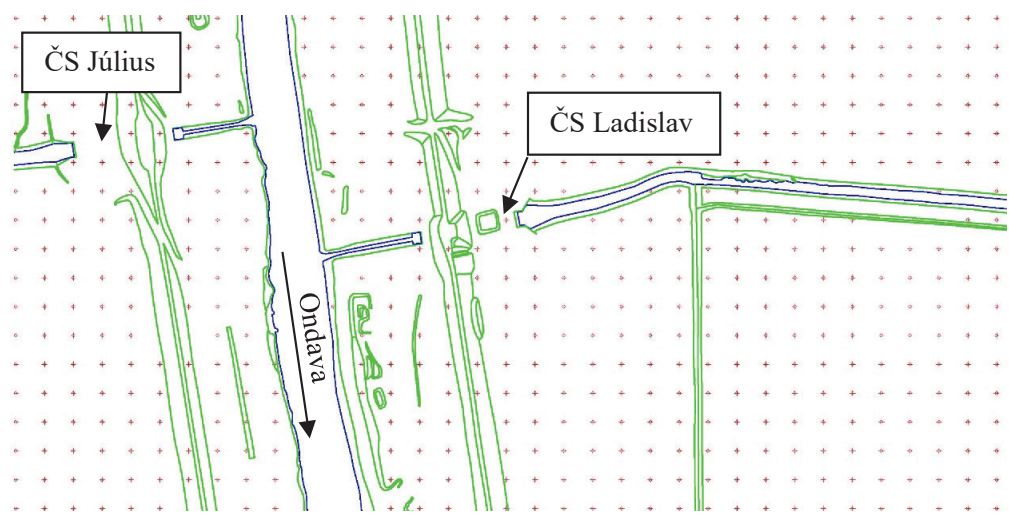

Obr. 2 Čast' digitálneho modelu terénu (DTM) z oblasti ČS Ladislav a Július.

\section{Hydrologické podklady}

Úsek Horovce-Hraň bol vybratý na simuláciu hladinového režimu, pretože nad (proti prúdu) bočným priepadom sa najbližšie nachádza vodomerná stanica (VS) Horovce a pod (po prúde) priepadom je na Ondave vodomerná stanica na ČS Hraň. Pre VS Horovce zhotovuje SHMÚ pravidelne konzumčnú krivku, takže v tomto profile sa dá odvodit' prietok, čo bola aj horná okrajová podmienka pre neustálené prúdenie. VS Hraň prináša iba záznam o polohe hladiny, tieto údaje sa použili pri kalibrácii matematického modelu, a to dolnej okrajovej podmienky (sklon čiary energie). Celková dížka 1-D modelu (dížka toku medzi stanicami Horovce a Hraň) je približne 18,0 km. Obr. 3 zobrazuje jednotlivé hydrologické podklady. 


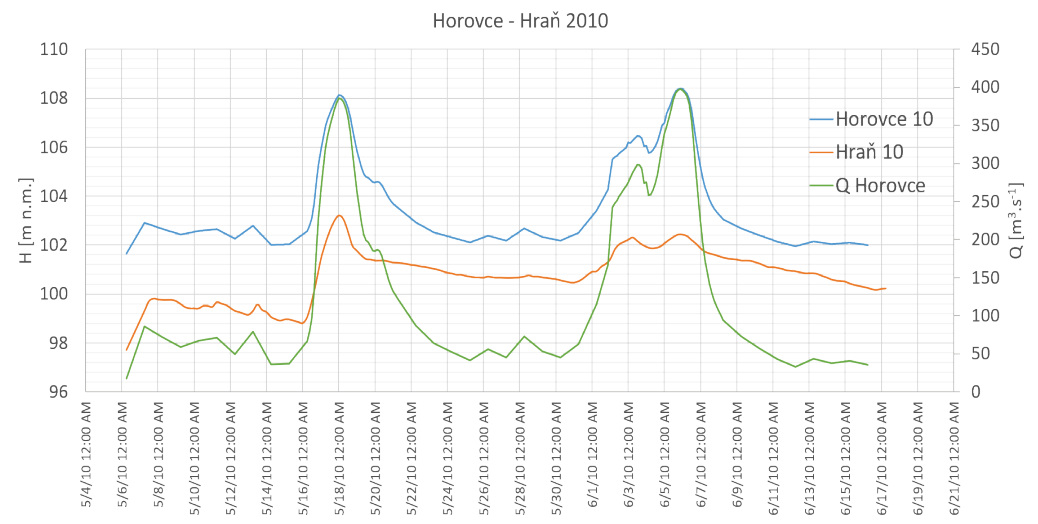

Obr. 3 Záznam z vodomerných staníc Horovce a Hraň počas povodne v roku 2010.

\section{Metodika riešenia}

V prvej fáze riešenia bol zostavený 1-D model. Priečne profily boli generované každých $200 \mathrm{~m}$ a v mieste priepadu hustejšie. Prvý odhad určenia drsnosti podl’a Manninga v kynete $\left(\mathrm{n}_{\mathrm{k}}\right)$ a bermách $\left(\mathrm{n}_{\mathrm{b}}\right)$ bol na základe rekognoskácie terénu určený na $n_{k}=0,042$ a $n_{b}=0,100$. Tieto hodnoty boli pri kalibrácii modelu určené na $n_{k}=0,0601$ a $n_{b}=0,143$. Horná okrajová podmienka bola počas všetkých výpočtov nemenná (prietoky zaznamenané v Horovciach), ale dolná okrajová podmienka sa menila. Počas prvej kalibrácie drsnosti sa použil záznam polohy hladiny v Hrani, tento prináša relevantné informácie iba do chvíle prietrže ochrannej hrádze, preto bola zamenená počas druhej kalibrácie za sklon čiary energie (ie) . Jej sklon bol kalibráciou určený na $i_{e}=0,3 \%$.

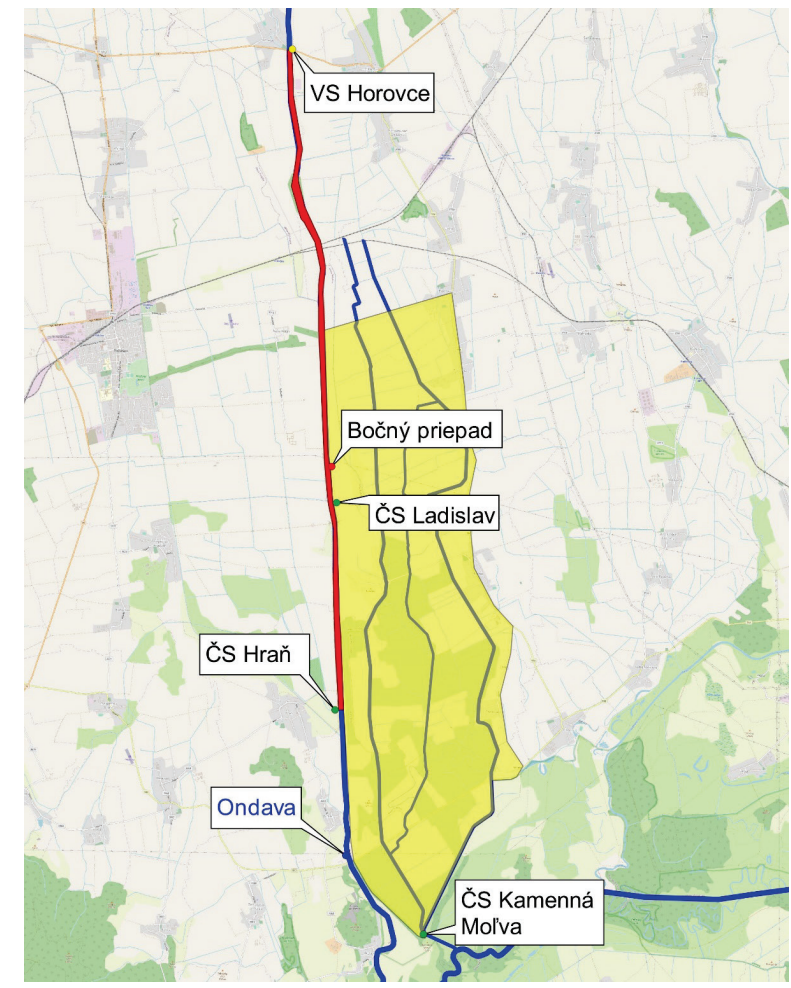

Obr. 4 Výpočtové oblasti kombinovaného 1-D a 2-D modelu. 
Pri 2-D modelovaní je nutné zvolit' si aj výpočtovú oblast', čo je vlastne v základe štvorcová siet', v ktorej prebieha výpočet. Náročnost' výpočtu nezáleží len od vel'kosti siete, ale aj od vel'kosti štvorca. Malé štvorce by síce priniesli presnejší výpočet, ale zvýšili by dobu výpočtu na neprípustné hodnoty. Preto sa pristúpilo k väčším štvorcom $(10 \mathrm{~m})$ a $\mathrm{k}$ ich zjemňovaniu v mieste výraznejšej zmeny morfológie. Hornú okrajovú podmienku teda prítok do oblasti je zabezpečený bočným priepadom, ktorý sa zadával v 1-D modeli. Dolnú okrajovú podmienku (odtok z oblasti) tvorí sklon čiary energie. Odtok z oblasti bol určený v najnižšom bode územia, kde sú vedené aj odvodňovacie kanály a to na ČS Kamenná Mol’va. Sklon čiary energie bol zvolený na hodnotu 0,2 \%o a bol určený na základe priemerného pozdížneho sklonu územia. Pre celé územie sa zvolila jednotná drsnost' $\mathrm{n}_{\mathrm{t}}=0,045$ a vychádzala z rekognoskácie terénu. Ked’že neexistuje žiaden záznam, kedy bol bočný priepad prelievaný bez prietrže hrádze s presným záznamom zaplavenej oblasti, nie je možné 2-D model kalibrovat'v dôsledku nedostatku údajov [5]. Obr. 4 zobrazuje červenou farbou oblast' toku, ktorá bola počítaná 1-D modelom a žltá farba ohraničuje 2-D výpočtovú oblast'. Jednalo sa o kombinovaný 1-D a 2-D model.

\section{VÝPOČET}

Pri simulácii povodne z 2010 roku sa uvažovalo s neprelomením ochranných hrádzí. Ďalej sa počítalo s vylievaním vody do mimo hrádzového priestoru iba v mieste priepadu, čo by sa zabezpečilo dočasným navýšením hrádzí, napríklad použitím vriec. Pri výpočte boli zvolené 2 alternatívy výpočtu, ktoré sú odlišné výškou priepadu:

- $\quad$ Alt. 0 - súčasný stav, priepad vo výške 104,70 m n.m.

- $\quad$ Alt. 1 - priepad znížený o 0,5 m (104,20 m n.m.)

Skúmala sa poloha hladiny voči ochranným hrádzam, prepadnutý objem vody a zatopená plocha, tieto údaje sú uvedené v Tab. 2.

Tab. 2 Porovnanie alternatív 0 a 1.

\begin{tabular}{cccccc}
\hline & $\begin{array}{c}\text { H } \\
{[\mathbf{m ~ n . m . ]}}\end{array}$ & $\begin{array}{c}\mathbf{Q}_{\mathbf{P K}} \\
{\left[\mathbf{m}^{\mathbf{3}} \cdot \mathbf{s}^{-\mathbf{1}}\right]}\end{array}$ & $\begin{array}{c}\mathbf{V}_{\mathbf{P}} \\
{\left[\mathbf{m i l} . \mathbf{m}^{\mathbf{3}}\right]}\end{array}$ & $\begin{array}{c}\mathbf{A z}_{\mathbf{Z}} \\
{[\mathbf{h a}]}\end{array}$ & $\begin{array}{c}\mathbf{d} \\
{[\mathbf{k m}]}\end{array}$ \\
\hline Alt. 0 & 104,86 & 365,00 & 4,073 & 1304 & 2,4 \\
Alt. 1 & 104,57 & 290,00 & 14,514 & 2598 & 0,3 \\
\hline
\end{tabular}

kde $H$ je nadmorská výška hladiny pri kulminačnom prietoku, $Q_{\mathrm{PK}}$ je kapacita koryta po hranu priepadu, $V_{\mathrm{P}}$ je pretečené množstvo vody cez priepad, $A_{z}$ je približná zaplavené plocha a $d$ je dížka preliatych úsekov.

Podl'a množstva preliatych úsekov sa môže zdat', že nižšia poloha priepadu by bola najvhodnejšia. Musíme si však uvedomit', že pri Alt. 1 začne voda cez priepad tiect' skôr a tým sa ohrozí aj väčšie územie. Podl'a simulácií by bola ohrozená ČS Ladislav a okrajové časti obce Hradištská Molvva. Taktiež by došlo k zatopeniu jedinej prístupovej cesty do spomínanej obce. K zatopeniu štátnej cesty Oborín - Sirník by nemalo dôjst' ani pri Alt. 1. Povodeň by v oboch prípadoch zaplavila predovšetkým pol'nohospodársku pôdu a lúky. Osídlené oblasti by mali byt' minimálne ohrozované nepriaznivým vplyvom povodne, avšak pri Alt. 1 hrozí okrem väčšieho a dlhšieho zatopenia pozemkov ešte aj zaplavenie ČS Kamenná Mol’va.

\section{ZNÍŽENIE ZAPLAVOVANEJ PLOCHY}

Na zníženie následkov záplav bol navrhnutý polder. Ohradenie poldra bolo navrhnuté z juhu vyvýšením prístupovej cesty na ČS Ladislav a z východnej strany postupným l’avobrežným ohradzovaním Bočného („,F“), Spojovacieho a Brehovského („D“) kanála. Zo západnej strany tvorí ohradenie poldra ochranná hrádza Ondavy. Severná čast' je vd’aka stúpajúcemu terénu bez ohradenia. Ďalej bolo nutné navrhnút' ochranu pre ČS Ladislav, ktorá by pozostávala z násypu zaviazaného do hrádze Ondavy a zo stavidla na prívodnom kanály.

Takéto pomerne rozsiahle ohradenie umožňuje pri odvádzaní vody využit’ kapacitu všetkých troch kanálov vedúcich na ČS Kamenná Mol’va („E“, „F“ a „D“) a prečerpávanie vody do Ondavy cez ČS Ladislav.

Pri simulácii povodne z roku 2010 a súčasnej polohe bočného priepadu (Alt. 0) je postačujúca výška hrádzí na kóte 100,15 m n.m. Pri znížení hrany priepadu o pol metra (Alt. 1) vyhovuje koruna vo výške $101,00 \mathrm{~m}$ n.m. Polder by znížil zaplavenú plochu na 550 ha pre Alt. 0 a na 900 ha pre Alt. 1. Doba zaplavenia poldra by bola pri Alt. 0 približne 3,5 dňa a pri alternatíve so zníženou hranou priepadu by bola 9 dní. 


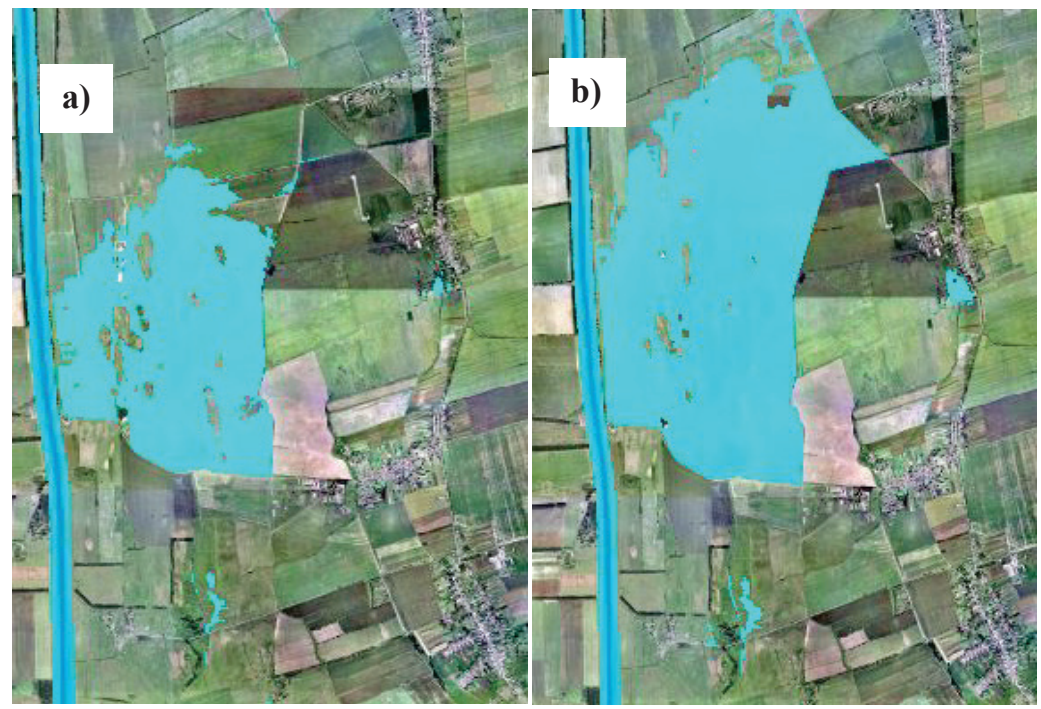

Obr. 5 Zaplavená plocha po výstavbe poldra a) - Alt. 0, b) - Alt. 1.

\section{ZÁVER}

Napriek enormnej snahe vodohospodárov - či už v minulosti alebo v prítomnosti - ochránit’ túto čast' Východoslovenskej nížiny pred povodňami, dochádza k zatápaniu územia v povodí Ondavy aj v dnešnej dobe. Jasným dôkazom toho sú aj v príspevku spomínané povodne z rokov 2004 a 2010.

Vybudovanie bočného priepadu malo byt' iba dočasným riešením. Komplexnejší návrh riešenia, ktorý pozostával najmä z odstránenia sedimentov z medzihrádzneho priestoru, nebol doposial' zrealizovaný. Problémy so záplavami v tejto oblasti sú spojené aj s materiálom, z ktorého sú ochranné hrádze vybudované (prevažne piesčité zeminy - miestny materiál).

Predkladaný príspevok analyzuje a hodnotí po hydraulickej stránke situáciu, ktorá vznikla vybudovaním pevného bočného priepadu na lavobrežnej hrádzi Ondavy zhruba 500 m povyše ČS Ladislav. Skúma alternatívne zníženie priepadu a zaoberá sa zatopeným územím v prípade využitia priepadu. Ďalej rieši zníženie zaplavovaného územia a jeho odvodnenie za pomoci kanálov a čerpacích staníc. Pri súčasnom stave koryta a ochranných hrádzí je podla matematického modelovania najvýhodnejším riešením zníženie hrany priepadu o $0,5 \mathrm{~m}$ a vybudovanie suchého poldra. Tieto úpravy však zabezpečia ochranu územia len do prietoku cca $Q=400 \mathrm{~m}^{3} \cdot \mathrm{s}^{-1}$.

$\mathrm{Na}$ ochranu územia pred transformovaným storočným prietokom $\left(\mathrm{Q}_{100 \mathrm{~T}}=720 \mathrm{~m}^{3} \cdot \mathrm{s}^{-1}\right)$ sú potrebné návrhy zahrňujúce odstránenie nánosov vzniknutých v medzihrádznom priestore a navýšenie ochranných hrádzí.

\section{Použité zdroje}

[1] TKÁČ, Ján. Súhrnná správa z povodňovej aktivity na tokoch v správe Povodia Bodrogu za obdobie 27.7.2004 -28.10.2005. Trebišov, 2005.

[2] KOLESÁROVÁ, Eva. Súhrnná správa o priebehu povodní, ich následkov a vykonaných opatreniach na tokoch v správe Povodia Bodrogu za obdobie 7.5.200- 16.11.2011. Trebišov, 2011.

[3] VLADIMÍR, Kundrát. Vodné družstvo na Ondave v Trebišove. Košice: Východoslovenské tlačiarne, vydavatel'ský odbor, 1998. ISBN 80-7132-012-9.

[4] KUTNÝ, Jozef. Sanácia l'avobrežnej hrádze Ondavy: Technická správa. 2005.

[5] KVĚTON, Radomil, ŠOLTÉSZ, Andrej, BAROKOVÁ, Dana. 2011. Mathematical modelling of flood protection on the Ondava River. In Acta Hydrologica Slovaca, vol. 12, no.2, pp. 304-311. 2644-6291 